\title{
Manajemen Lapas Super Maximum Security Dalam Perspektif Global
}

\author{
Robi Setiawan Tridesia \\ Politeknik IImu Pemasyarakatan \\ Tridesia33@gmail.com
}

\begin{abstract}
ABSTRAK
Penulisan artikel ini bertujuan untuk menjelaskan bagaimana system manajemen pemasyarakatan khususnya di lembaga pemasyarakatan super maximum security yang didasari dengan teori atau aturan internasional. Yang menjadi latar belakang penulisan ini adalah saat ini Negara Indonesia mulai merevitalisasi system pemasyarakatan yang dimana lapas menjadi ada 4 pengklasifikasian yaitu super maximum security, maximum security, medium security dan minimum security dan pada artikel ini berfokus kepada manajem lapas super maximum security karena ditinjau dari aturan-aturan dan SOP yang mengatur sistem lapas super maximum di Indonesia tidak ada suatu aturan internasional yang mendasarinya dan lapas super maimum security merupakan lapas yang mempunyai banyak tantangan dalam menjalankan sistemnya yaitu beresiko besar untuk melanggar HAM narapidana dan menimbulkan penyakit psikologis terhadap narapidana. Metode penelitian yang digunakan pada penulisan artikel ini adalah metode penelitian kualitatif yang bersifat studi pustaka (library research) yang menggunakan buku dan literature sebagai objek penelitian. Jenis penelitian yang digunakan adalah kualitatif, yaitu penelitian yang menghasilkan informasi berupa data deskriptif yang terdapat di dalam teks yang diteliti. Dalam hasil penelitan artikel ini dapat dijelaskan tentang bagaimana memanajemen lapas super maximum security dalam perspektif global, ada beberapa poin manajemen apa saja yang diatur oleh internasional dalam memanajemen lapas super maximum security seperti: perlakuan manusiawi dan martabat manusia, asesment narapidana, manajemen resiko, jumlah minimal narapidana yang ditahan di lapas super maximum security, diperlukan langkah restriktif, kondisi keamanan maksimum, pengamanan, perekrutan dan pelatihan petugas, kelompok khusus dan kesehatan mental.
\end{abstract}

Kata kunci: manajemen, lapas super maximum security, studi literature, internasional

\begin{abstract}
The writing of this article aims to explain how the correctional management system, especially in super maximum security correctional institutions based on international theory or rules. The background of this writing is that currently the State of Indonesia is starting to revitalize a penal system in which prisons are classified into 4 classifications namely super maximum security, maximum security, medium security and minimum security and in this article the focus is on super maximum security prison management because of the rules regulations and SOPs that regulate the super maximum prison system in Indonesia do not have an international rule that underlies and super maimum security prison is a prison that has many challenges in running the system which is at great risk to violate the inmates' human rights and cause psychological illnesses to prisoners. The research method used in writing this article is a qualitative research method that is library research that uses books and literature as research objects. This type of research is qualitative, which is research that produces information in the form of descriptive data contained in the text under study. In the research results of this article, it can be explained about how to manage super maximum security prisons in a global perspective, there are some management points that are regulated by international in managing super maximum security prisons such as: humane treatment and human dignity, prisoners' assessment, risk management, minimum amount prisoners detained in super maximum security prisons, require restrictive measures, maximum security conditions, security, recruitment and training of officers, special groups and mental health.
\end{abstract}

Keywords: management, super maximum prison security, literature study, international 


\section{PENDAHULUAN}

Manajemen merupakan sebuah kegiatan perencanaan, pengorganisasian, dan juga pengontrolan sumber daya yang dimiliki guna mencapai tujuan dengan efektif dan efisien. Menurut henry fayol definisi manajemen adalah sebuah proses pengorganisasian, perencanaan, pengkoordinasian, dan pengontrolan suatu tatanan organisasi untuk mencapai suatu tujuan tertenju dengan efektif dan efisien. Pemasyarakatan di Negara Indonesia memiliki arti sebagai sebuah kegiatan pembinaan yang dilakukan kepada narapidana atau yang disebut warga binaan pemasyarakatan berdasarkan system pemasyaratan, system pemasyarakatan adalah suatu tatanan tentang arah dan batasan serta cara untuk membina narapidana atau warga binaan pemasyarakatan agar mereka dapat menyadari kesalahannya dan berubah menjadi manusia yang lebih baik dan tidak lagi mengulangi tindakan yang melanggar hukum lagi sehingga dapat diterima kembali oleh masyarakat dan dapat berperan aktif dalam pembangunan Negara, dan dapat menjalankan hidup dengan wajar menjadi warga Negara yang baik dan bertanggung jawab.

Di dalam system pemasyarakatan memilik tempat untuk membina narapidana yang biasa disebut dengan Lembaga Pemasyarakatan (Lapas). Lembaga Pemasyarakatan (Lapas) di negara indonesia memilik arti sebagai sebuah tempat untuk membina narapidana yang didadasari dengan norma norma pancasila yang dilaksanakan secara terpadu antara Pembina, yang dibina dan masyarakat agar narapidana dapat menyadari kesalahannya dan menjadi manusia yang lebih baik dan tidak mengulangi tindak pidana kembali. Dalam program revitalisasi pemasyarakatan yang telah dicanangkan oleh Direktur Jenderal Pemasyarakatan pada dewasa ini Lapas memiliki klasifikasi berdasarkan tingkat resiko narapidana yang menghuni lapas, pengklasifikasian lapas antara lain adalah Lapas Super Maximum Security, Lapas Maximum Security, Lapas Medium Security dan Lapas Minimum Security. Didalam artikel ini akan membahas tentang lapas yang diperuntukan untuk narapidana beresiko tinggi yaitu lapas super maximum security. Lapas super maximum security adalah tempat untuk membina narapidana tingkat resiko tinggi untuk merubah perilakunya agar menjadi lebih baik dan menurunkan tingkat resikonya. yang dimaksut dengan resiko tinggi disini adalah narapidana yang dapat membahayakan Negara dan masyarakat. Lapas super maximum security adalah satu bentuk dari penataan kembali manajemen pemasyarakatan guna mengoptimalkan penyelenggaraan pemasyarakatan dalam tujuannya untuk membina narapidana agar tidak mengulangi tindak pidananya dan dapat berkontribusi dalam pembangunan Negara republik indonesia.

Dalam pelaksanaan manajemen lapas super maximum security di Indonesia untuk memenuhi tujuannya yaitu menurunkan tingkat resiko narapidana sudah diatur dalam Peraturan Menteri Hukum dan Ham Republik Indonesia Nomor 35 Tahun 2018 Tentang Revitalisasi Penyelenggaraan Pemasyarakatan Pasal 9 sampai dengan Pasal 12. Dalam pasal 9 Permenkumham RI No 35 Tahun 2018 berisi tentang penjelasan tentang lapas super maximum security adalah tempat untuk narapidana yang memiliki tingkat resiko tinggi guna merubah perilakunya dan menurunkan tingkat resikonya. Dalam pasal 10 menjelaskan tentang narapidana beresiko tinggi yang dimaksud adalah narapidana yang membahayakan Negara dan masyarakat serta sistem penahanan yang digunakan adalah sistem one man one cell. Pasal 11 menjelaskan tentang pemberian program pembinaan yang diberikan kepada narapidana beresiko tinggi di lapas super maximum security. Pembinaan yang diberikan adalah program pembinaan kesadaran beragama, program pembinaan kesadaran berbangsa dan bernegara, program pembinaan kesadaran hukum dan konseling psikologi. Program pembinaan yang diberikan dilakukan melalui hasil litmat dan rekomendasi dari tim pengamat pemasyarakatan. Program pembinaan dilakukan secara individual atau terpisah. Pasal 12 menjelaskan tentang pencatatan sikap dan perilaku harian narapidana yang dilakukan oleh wali pemasyarakatan dalam laporan harian sikap dan perilaku narapidana yang nantinya akan 
diberikan kepada pembimbing kemasyarakatan sebagai sumber data dalam melakukan penilaian dan penyusunan litmas. Dan apabila hasil penilaian menunjukan penurunan tingkat resiko yang sesuai dengan indikator narapidana akan dipindahkan ke lapas yang lebih rendah pengamanannya yaitu lapas Maximum security. Pemindahan narapidana dilakukan berdasarkan rekomendasi tim pengamat pemasyarakaan

Dalam kondisi saat ini pelaksanaan lapas super maximum security di Negara Indonesia hanya diatu oleh peaturan menteri dan SOP yang didasari oleh dasar hukum tentang pemasyarakatan dan pelayanan public di Negara Indonesia saja. Sedangkan lapas dengan keamanan tinggi dapat menjadi kontradiksi dimana makna dan harapan sulit ditemukan namun rehabilitasi dan reformasi diharapkan. Kegiatan yang memungkinkan kelangsungan hidup dan pertumbuhan psikologis sering dilarang atas dasar keamanan. Namun standart internasional yang relevan barkaitan dengan pengelolaan tahanan biasanya tidak secara khusus berfokus pada tahanan yang dinilai beresiko tinggi. PBB telah mengembangkan rekomendasi untuk manajemen tahanan yang dijatuhi hukuman seumur hidup, tetapi tidak semua tahanan seumur hidup itu memiliki resiko tinggi. Dewan eropa telah menjadi badan regional paling aktif dalam hal mengembangkan rekomendasi untuk pengelolaan tahanan jangka panjang dan hukuman seumur hidup.

Di Negara Indonesia, manajemen lapas perlu merujuk pada instrument internasional, stadart dan norma yang mencakup perlakuan terhadap narapidana secara umum, karena ini berlaku untuk seluruh narapidana. Namun juga membutuhkan panduan khusus tentang cara terbaik untuk menerapkannya prinsip pada manajemen narapidana beresiko tinggi yang efektif akan menimbulkan tantangan khusus dan kompleks.ada persyaratan tertentu yang harus dipenuhi jika Negara Indonesia ingin mematuhi kewajiban untuk menghormati hak asasi dan martabat narapidana dan memenuhi pembinaannya. Termasuk menyediakan akomodasi yang memadai, kondisi yang higienis, pakaian dan tempat tidur, makanan dan minuman, akses ke udara segar dan olahraga, kontak dengan manusia (keluarga, kerabat, penasihat hukum, dan kegiatan yang membangun. Standart internasional jelas mensyaratkan bahwa hukuman yang dijatuhkan semata mata merupakan perampasan kebebasan. Dalam melaksanakan pembinaan narapidana tidak boleh mendapat resiko penyakit, penurunan kesehatan mental atau bahkan kematian karena kondisi atau kurangnya perawatan yang tepat. Tahanan tidak boleh mengalami kondisi dimana harkat dan marabat mereka sebagai manusia direndahkan. Narapidana juga harus diberikan kesempatan untuk mereformasi dan merehabilitas diri mereka sendiri sehingga mereka pada saat nanti bebas memiliki kemampuan dan memberikan kontribusi yang positif kepada masyarakat. Semua prinsip dasar tersebut berlaku sama untuk narapidana resiko tinggi mereka memiliki hak yang sama seperti narapidana yang berada di lapas yang tingkat keamanannya lebih rendah.

Narapidana yang berada di lapas high risk dinilai sebagai ancaman terhadap keamanan Negara dan keselamatan masyarakat. Dengan diberikan tugas dan tanggung jawab seperti itu manajemen lapas harus memastikan bahwa keseimbangan yang tepat dipertahankan antara perawatan dan pengontrolan antara kewajiban petugas lapas untuk menghormati harkat dan martabat manusia dan hak hak narapidana dengan tugas petugas lapas untuk melindungi masyarakat dari kejahatan. Petugas lapas juga memiliki tugas untuk mewujudkan reintegrasi sosial para narapidana. Ini merupakan tugas yang menantang yang harus dihadapi oleh administrasi lapas dan ujian bagi keprofesionalitasan para petugas pemasyarakatan.

Dalam praktiknya, pada pandangan yang salah lapas dengan keamanan tinggi mendapat pandangan yang restriktif, represif dan brutal bahwa menurut pandangan tersebut menganggap tidak ada cara lain untuk menahan narapidana beresiko tinggi dengan aman. Dalam artikel ini menjelaskan tentang bagaimana narapidana dinilai sebagai resiko tinggi dikelola dengan aman sementara pada saat yang sama dapat memenuhi hak narapidana untuk mendapatkan hak komunikasi, interaksi sosial dan rehabilitasi. Ini menekankan bahwa semua 
tahanan harus menyediakan peluang untuk bekerja dengan mendapat upah atau premi, mendapatkan pendidikan, menjalankan ibadah, olahraga dan rekreasi. Dengan artikel ini memungkinkan untuk otoritas pemasyarakatan dan pemangku kepentingan terkait pemasyarakatan dapat dipakai untuk mengembangkan kebijakan dan strateginya dalam pengelolaan narapidana beresiko tinggi dengan efektif dan tepat sasaran.

Di tingkat internasional ada sejumlah badan dengan mandat untuk mengatur kondisi penjara, yaitu :

- The International Committee of the Red Cross (ICRC);

- The Spesial Rapporteur on Torture and other cruel, inhuman or degrading treatment or punishment. Organisasi yang ditunjuk oleh Dewan Hak Asasi Manusia, yang dapat mempertimbangkan pengaduan dan melakukan kunjungan ke suatu Negara guna mencari fakta;

- The Subcommitte on the Prevention of Torture and Other Cruel, Inhuman or Degrading Treatment of Punishment (SPT).

- The Committee against orture, dibentuk berdasarkan pasal 17 Konvensi terhadap penyiksaan dan perlakuan atau hukuman lain yang kejam, tidak manusiawi atau merendahkan martabat.

Praktek yang baik dalam manajemen lapas resiko tinggi adalah dengan memfasilitasi pemantauan kunjungan oleh berbagai badan nasional untuk memastikan bahwa perawatan narapidana beresiko tinggi sesuai dengan instrument, peraturan dan rekomendasi nasional dan internasional termasuk Lembaga Swadaya Masyarakat (LSM), asosiasi profesi, organisasi keagamaan dan media. Sementara aturan PBB untuk perlakuan terhadap narapidana yang disebut dengan Nelson Mandela Rules serta sejumlah instrument khusus yang menyoroti pentingnya pemantauan dan inspeksi kelembagaan. Didalam artikel ini akan membahas tentang arah dan pedoman dalam memperlakukan narapidana beresiko tinggi sesuai dengan aturan internasional.

\section{METODE PENELITIAN}

Metode yang diambil dalam penulisan artikel ini adalah metode penelitian kualitatif yang bersifat studi pustaka (library research) yang menggunakan buku dan literature sebagai objek yang utama (Hadi, 1995: 3). Jenis penelitian yang digunakan adalah kualitatif, yaitu penelitian yang menghasilkan informasi berupa data deskriptif yang terdapat di dalam teks yang diteliti (Mantra, 2008: 30).

\section{PEMBAHASAN}

Didalam manajemen lapas high risk di Negara Indonesia masih sedikit aturan yang mengatur mengenai pembinaan Lapas yang diperuntukan bagi narapidana beresiko tinggi. Karena manajemen narapidana berisiko tinggi menimbulkan tantangan khusus bagi administrasi lembaga pemasyarakatan dalam memastikan bahwa keseimbangan yang tepat dipertahankan antara langkah-langkah keamanan dan perawatan tahanan sesuai dengan hak asasi manusia yang mendasar maka dalam pembahasan ini bertuliskan pegangan yang dianut oleh lapas high risk internasional. Administrasi penjara memiliki tugas untuk mendukung, sejauh mungkin, prospek reintegrasi sosial semua narapidana. Dalam kasus napi berisiko tinggi, yang profil risiko dan kebutuhannya kompleks dan beragam.

\section{Perlakuan Manusiawi dan Martabat Manusia.}

Prinsip dasar yang diatur dalam hukum internasional dan semua standar internasional yang relevan dengan norma yang terkait dengan perlakuan terhadap tahanan adalah bahwa perlakuan mereka harus bersifat manusiawi dan menghormati martabat yang melekat dari pribadi manusia. Penyiksaan, tidak manusiawi dan merendahkan martabat manusia dilarang berdasarkan hukum internasional sehubungan dengan semua narapidana, termasuk mereka yang dianggap berisiko tinggi. Sementara itu 
larangan mutlak ini bisa dibilang merupakan aspek paling mendasar dari penghormatan terhadap martabat manusia, prinsip perlakuan manusiawi mencakup banyak aspek dalam pengelolaan lapas. Dalam prinsip dasarnya, yang berlaku untuk semua tahanan, standart mimimum rules PBB menyatakan bahwa:

"Sistem penjara dengan pemisahan seharusnya tidak akan ada, kecuali sebagai insidental terhadap pemisahan yang dapat dibenarkan atau mempertahankan disiplin, memperburuk penderitaan yang melekat dalam situasi seperti itu. "

penderitaan yang melekat dalam situasi seperti itu. "

"pemasyarakatan harus berusaha untuk meminimalkan perbedaan antara kehidupan penjara dan hidup bebas yang cenderung mengurangi tanggung jawab para tahanan atau rasa hormat untuk martabat mereka sebagai manusia".

Langkah-langkah yang harus diambil berdasarkan prinsip-prinsip ini berhubungan dengan kondisi penjara, akses ke makanan, air dan sanitasi, perawatan kesehatan yang memadai, serta untuk melakukan kontak dengan dunia luar, khususnya dengan keluarga narapidana. Poin yang ditegaskan kembali oleh Komite Hak Asasi Manusia dalam Komentar Umumnya terhadap Pasal 10 dari Kovenan Internasional tentang Hak Sipil dan Politik (ICCPR):

"Memperlakukan semua orang yang dirampas kebebasannya dengan manusiawi dan dengan menghormati kebebasan mereka. martabat adalah aturan fundamental dan berlaku secara universal. Alhasil, aplikasi peraturan ini, sebagai minimum, tidak dapat bergantung pada sumber daya material yang tersedia di sebuah Negara.

Aturan ini harus diterapkan tanpa perbedaan dalam bentuk apa pun, seperti ras, warna kulit, jenis kelamin, bahasa, agama, opini politik atau lainnya, asal kebangsaan atau sosial, properti, kelahiran atau status lainnya."

Hubungan antara petugas dan narapidana, serta prosedur dan praktik penjara juga penting dalam hal ini. Misalnya, cara petugas penjara menangani para narapidana; bagaimana penggeledahan dilakuka apakah privasi tahanan dihormati. Ketika mereka diminta untuk melepas pakaian, apakah pembatasan digunakan secara tidak perlu dan dalam sebuah cara yang memalukan, apakah privasi di toilet dan kamar mandi dihormati, apakah petugas diminta mengenakan seragam khusus adalah semua cara di mana kemanusiaan narapidana dan martabat bisa dihormati atau tidak. Menggunakan bahasa yang tidak sopan, menundukkan tahanan untuk rutinitas yang memalukan atau praktik yang tidak memiliki justifikasi keamanan, merupakan pelanggaran hak fundamental mereka untuk diperlakukan dengan hormat karena martabat mereka sebagai manusia.

Prinsip-prinsip di atas merupakan dasar bagi manajemen yang efektif untuk mewujudkan kemanusiaan dan keadilan

Sistem lapas termasuk di fasilitas tempat tahanan berisiko tinggi ditahan. Keamanan tambahan diperlukan langkah-langkah untuk memastikan bahwa narapidana semacam itu tidak melarikan diri dan bahwa mereka tidak menyebabkannya kerusakan pada diri mereka sendiri atau orang lain. Penting untuk dicatat dalam hal ini bahwa merawat tahanan dengan kemanusiaan tidak menghalangi menjaga keamanan dan ketertiban di lapas, tetapi sebaliknya, merupakan hal mendasar untuk memastikan bahwa penjara aman. Praktek yang baik dalam manajemen lapas telah menunjukkan kapan hak asasi manusia dan martabat para narapidana dihormati dan mereka diperlakukan secara adil. Jauh lebih kecil kemungkinannya untuk menyebabkan gangguan dan lebih mungkin untuk menerima kebijakan petugas lapas.

\section{Jumlah Minimal Narapidana yang ditahan di Lapas Super Maximum Security}

Kondisi jumlah narapidana yang benar-benar berisiko melarikan diri atau 
beresiko keselamatan Negara dan masyarakat biasanya cukup kecil dan yang penting hanya narapidana itu saja dinilai sebagai beresiko tinggi. Prinsip ini membutuhkan asesment risiko yang tepat pada saat narapidana masuk ke lapas untuk memutuskan yang tingkat keamanan yang sesuai untuk setiap narapidana. Itu juga membutuhkan ulasan rutin agar narapidana yang perilakunya tidak lagi mewakili risiko dialokasikan kembali ke kondisi yang tidak terlalu ketat. Narapidana seharusnya tidak ditempatkan dalam kondisi keamanan tinggi hanya berdasarkan lamanya hukuman mereka, seperti halnya di beberapa yurisdiksi yang mengarahkan bahwa narapidana yang memiliki masa tahanan lama belum tentu beresiko tinggi. Narapidana yang dihukum seumur hidup di bawah hukuman mati, sering kali secara otomatis ditempatkan pada lapas maximum security. Proporsi tahanan yang signifikan dengan hukuman seumur hidup atau lama seringkali dianggap beresiko tinggi, dan pada kenyataannya sebagian besar tidak menunjukan perilaku beresiko tinggi.

Ketika terlalu banyak narapidana ditahan dalam kondisi keamanan tinggi, mereka akan mempunya persepsi bahwa tidak ada keadilan, menyebabkan ketegangan dan ketidak puasan, sementara petugas pemasyarakatan kurang bisa mengawasi mereka karena terlalu banyak narapidana yang dianggap beresiko tinggi di penjara di lapas super maximum security dan juga akan menimbulkan beban lebih terhadap keuangan, sumber daya manusia dan teknis menjalankan program pembinaannya.

\section{Asesment Narapidana.}

Sistem assessment resiko dan kebutuhan merupakan prasyarat untuk mematuhi prinsip individualisasi, kalimat ini berasal dari Peraturan Standar Minimum PBB tentang Perlakuan Terhadap Narapidana. Penilaian masing-masing narapidana harus dilakukan pada saat masuk ke penjara dan diulangi secara berkala sepanjang hukumanmya. Penilaian harus mencakup resiko pelarian, risiko yang akan narapidana berikan terhadap masyarakat apabila melarikan diri, risiko yang dinilai dari bagaimana mereka mematuhi tata tertib dan disiplin di penjara dan risiko yang mungkin ditimbulkannya kepada publk di penjara. Penilaian harus dibedakan dengan jelas antara berbagai jenis risiko yang ditimbulkan oleh narapidana dan memperhitungkannya di dalam kategorisasi dan alokasi. Penilaian juga harus mengidentifikasi kebutuhan rehabilitasi narapidana sehingga rencana hukuman mencakup intervensi yang sesuai dengan reintegrasi sosial narapidana. Kemudian penilaian kesehatan, khususnya terkait dengan kesehatan mental dan risiko melukai diri sendiri atau bunuh diri, harus dipertimbangkan secara matang. Sangat penting untuk memahami bahwa penilaian risiko dan kebutuhan adalah proses yang berkelanjutan dan dinamis. Penilaian harus diulang secara berkala untuk memastikan bahwa hukuman masih relevan diberikan kepada narapidana. Manajemen penjara harus responsif terhadap perubahan penilaian, apakah ini merupakan peningkatan tingkat risiko atau perubahan positif yang mungkin diperlukan untuk memindahkan narapidana ke lapas yang klasifikasinya lebih rendah pengamanannya.

\section{Manajemen Resiko.}

Penilaian risiko dan kebutuhan harus selalu dikaitkan dengan manajemen risiko dan kebutuhan. Manajemen risiko mengacu pada proses penerapan berbagai tindakan di penjara, dalam periode pasca pembebasan dengan tujuan mengurangi risiko (mantan) narapidana untuk melakukan atau menghasut tindakan kekerasan dan mengganggu saat berada di penjara dan menceritakan kembali tentang kejahatan. Strategi manajemen risiko narapidana berisiko tinggi harus memiliki tujuan jangka panjang untuk mereka kembali ke masyarakat dan harus memastikan bahwa ada kesinambungan di antara keduanya periode pada saat narapidana ditahan dan periode pasca- 
pembebasan. Dalam rekomendasinya tentang manajemen pelanggar hukum, Dewan Eropa merekomendasikan bahwa:

"All plans developed with this aim in mind should include: rehabilitative and restrictive measures to reduce the likelihood of reoffending in the longer term, while affording the necessary level of protection to others; measures to support the individual to address personal needs; contingency measures to respond promptly to indications of either dete-rioration or imminent offending; and appropriate mechanisms to respond to indications of positive changes."

"Semua rencana yang dikembangkan dengan tujuan ini harus mencakup: rehabilitasi dan restriktif, langkah - langkah untuk mengurangi kemungkinan reoffending dalam jangka panjang, sambil memberikan

tingkat perlindungan yang diperlukan untuk orang lain; langkah-langkah untuk mendukung individu untuk mengatasi kebutuhan pribadi; langkah-langkah darurat untuk segera menanggapi indikasi deterioration atau pelanggaran segera; dan mekanisme yang tepat untuk menanggapi indikasi perubahan positif. "

Secara umum, manajemen risiko dapat dipecah menjadi tiga komponen:

pencegahan, pemantauan da

intervensi. Masing-masing komponen ini harus diinformasikan dan dibenarkan oleh temuan penilaian risiko dan kebutuhan.

- Pencegahan: Pencegahan mengacu pada langkah-langkah keamanan yang diambil untuk meminimalkan risiko. Ini mungkin termasuk, misalnya, pembatasan yang diberikan pada komunikasi tahanan dan pemisahan tahanan peran kepemimpinan dari orang lain), di antara tindakan pencegahan lainnya.

- Pemantauan: Ini adalah proses di mana pengawas dan pengamatan terus dilakukan. Intervensi yang sesuai dilakukan ketika risiko seperti kerusuhan, pelarian atau menyakiti diri sendiri terjadi atau membutuhkan sinyal untuk itu.

Pemantauan dapat menghasilkan prediksi risiko tertentu yang muncul. Ketika ini terjadi, intervensi konstruktif perlu dilakukan untuk mencegah kejadiannya.

- Intervensi: Intervensi mencakup tindakan pembatasan yang diambil untuk meminimalkan risiko dalam jangka pendek dan program yang bertujuan untuk menghilangkan atau mengurangi penyebab risiko yang mendasari, dengan tujuan untuk mencapai hasil positif yang bersifat jangka panjang. Penyebab yang mendasari biasanya kompleks, tetapi dapat mencakup faktor sosial, ekonomi dan pendidikan, serta satu atau lebih faktor yang disebut "kriminogenik", yaitu bentuk perilaku yang cenderung mengarah pada kegiatan kriminal. Memberikan kegiatan kepada narapidana yang bersfat konstruktif yang mencakup berbagai kegiatan dan program untuk mengurangi risiko yang mereka timbulkan dan memungkinkan reintegrasi sosial. Kegiatan dan program tersebut meliputi pendidikan, pelatihan kejuruan, pekerjaan, olahraga, rekreasi, pelayanan ibadah, program yang membahas kebutuhan kriminogenik dan kebutuhan yang membantu mempersiapkan tahanan untuk dibebaskan.

\section{Diperlukan Langkah Restriktif.}

Prinsip dasar lain dari
manajemen penjara yang baik adalah
bahwa narapidana harus tunduk paling
tidak aturan yang diperlukan untuk
melindungi masyarakat, narapidana
lainnya dan petugas penjara. Pembatasan
yang diberikan pada hak-hak narapidana
harus didasarkan pada penilaian risiko dan
kebutuhan individu yang dilakukan setelah
masuk penjara, ditinjau secara berkala dan
dimodifikasi seperlunya.
Penilaian risiko dan kebutuhan harus selalu
mematuhi prinsip-prinsip berikut:


- Legalitas: Semua tindakan pembatasan yang dikenakan pada tahanan harus sesuai dengan hukum internasional dan nasional, dan memiliki tujuan yang sah.

- Kebutuhan: Langkah-langkah harus diperlukan, yaitu harus jelas bahwa menggunakan lebih sedikit sarana yang membatasi tidak akan memenuhi tujuan untuk memastikan keselamatan dan keamanan.

- Proportionalitas: Ukuran restriktif harus proporsional dengan risiko yang ditimbulkan, dengan keseimbangan yang tepat antara perlindungan hak-hak dasar tahanan dan campur tangan Negara yang sah dalam pelaksanaan hak-hak ini. Gangguan seperti itu harus sedapat mungkin tidak mengganggu untuk memenuhi tujuan memastikan keamanan dan ketertiban di penjara, dan dikenakan hukuman sesingkat mungkin.

- Akuntabilitas: Proses pengambilan keputusan harus transparan dan catatan harus disimpan dari penilaian dan proses pengambilan keputusan membenarkan kebutuhan untuk pembatasan diberlakukan.

- Non-diskriminasi: Keputusan harus objektif dan tidak memihak, dengan mempertimbangkan hanya faktor-faktor yang relevan. Seharusnya tidak ada diskriminasi terhadap kelompok tahanan tertentu, berdasarkan ras, warna kulit, agama, etnis, kebangsaan, jenis kelamin, identitas gender, orientasi seksual, pandangan politik atau faktor lainnya.

Penerapan prinsip-prinsip di atas memastikan bahwa hanya sejumlah kecil napi yang akan melakukannya perlu diadakan dalam kondisi keamanan tinggi, sehingga memfasilitasi pengawasan yang efektif dan pengelolaan. Ini juga memastikan bahwa sumber daya manusia dan keuangan tidak terbuang untuk menahan sejumlah besar tahanan dalam kondisi yang lebih ketat daripada yang diperlukan.

\section{Kondisi Keamanan Maksimum}

Sejumlah tahanan cenderung mewakili risiko keamanan yang sangat tinggi, dan mungkin karena itu memerlukan penahanan dalam kondisi keamanan maksimum khusus. Jika sistem penilaian bekerja dengan efektif, proporsi narapidana yang perlu ditahan dalam kondisi khusus seperti itu harus sangat kecil. Tahanan semacam itu biasanya ditampung jauh dari yang nsrspidsns ysng lain, baik di penjara khusus keamanan tinggi atau di unit khusus di dalam penjara dengan tingkat keamanan yang berbeda. Di banyak yurisdiksi, pembatasan diberikan pada hak tahanan semacam itu di samping pengaturan tahanan mereka yang sangat terbatas. Pembatasan seperti itu mungkin berlaku untuk akses narapidana ke olahraga, kegiatan, hubungan dengan tahanan lain, komunikasi dengan dunia luar, dan barang-barang pribadi yang diperbolehkan dalam sel, antara lain. Di beberapa negara, tahanan seperti itu akan diborgol, masing-masing memiliki waktu rutin mereka untuk meninggalkan sel mereka, termasuk ketika melakukan latihan di luar ruangan di halaman latihan yang aman. Prinsip-prinsip legalitas, keharusan, akuntabilitas, proporsionalitas, dan non-diskriminasi diuraikan di atas harus sama-sama diterapkan pada keputusan tentang menahan tahanan secara maksimal kondisi keamanan. Tahanan semacam itu harus, dalam batas-batas unit penahanan mereka, menikmati rezim yang relatif santai untuk mengimbangi pembatasan pengaturan hak asuh mereka. Mereka harus dapat bergaul dengan tahanan lain di unit mereka, memiliki akses ke berbagai penjara kegiatan dan memiliki kontak dengan dunia luar. Petugas penjara harus dapat mempertahankan 
keamanan dan kontrol dengan cara lain selain melarang semua jenis kegiatan. Meskipun mungkin tampaknya menjadi pilihan yang lebih mudah, itu menghambat kemungkinan rehabilitasi tahanan dan tidak sesuai dengan standar internasional. Pembatasan tambahan diberikan pada tahanan tersebut harus didasarkan pada penilaian risiko individual, yang harus ditinjau secara berkala dasar. Di beberapa yurisdiksi, tahanan yang dianggap sangat berbahaya atau berisiko tinggi ditahan kurungan isolasi selama bertahun-tahun dan berpotensi selama durasi hukuman mereka. Ini bertentangan dengan Aturan Minimum Standar PBB untuk Perlakuan Terhadap Tahanan, yang mensyaratkan bahwa kurungan isolasi hanya boleh digunakan dalam kasus luar biasa untuk sesingkat waktu yang mungkin, dan yang melarang soliter tidak terbatas atau lama (lebih dari 15 hari) kurungan.

\section{Pengamanan.}

Selain keseimbangan yang tepat antara penerapan langkah-langkah keamanan dan menghormati martabat manusia dari para tahanan, perlu juga ada keseimbangan di antara para tahanan jenis langkah-langkah keamanan yang diterapkan. Keamanan di penjara dipastikan dengan:

a) sarana fisik, dinding, palang pada jendela, kunci dan pintu, sistem alarm, dll

b) sarana prosedural, yaitu prosedur dan aturan yang berkaitan dengan pergerakan tahanan di sekitar fasilitas, milik mereka dapat menyimpan, mencari tahanan dan akomodasi mereka, dll.; dan

c) keamanan dinamis, membutuhkan petugas penjara yang siaga yang berinteraksi dengan tahanan secara positif dan melibatkan mereka dalam kegiatan yang konstruktif, yang memungkinkan petugas untuk mengantisipasi dan mencegah munculnya masalah.
Keseimbangan yang tepat harus dipertahankan antara dimensi keamanan fisik, prosedural dan dinamis dalam kasus semua tahanan, termasuk tahanan berisiko tinggi. Keseimbangan yang tepat untuk mencegah pelarian dan menjaga ketertiban akan tergantung pada sejumlah faktor, seperti kondisi fasilitas penjara, tingkat teknologi yang tersedia, jumlah petugas dan jenis narapidana yang ditahan di penjara. Misalnya, di mana keamanan fisik lemah, seperti mungkin menjadi kasus di lingkungan sumber daya rendah dan pasca konflik, prosedural dan dinamis keamanan menjadi semakin penting.

\section{Perekrutan dan Pelatihan Petugas.}

Petugas harus dipilih dengan benar dan menerima pelatihan khusus untuk bekerja dengan tahanan berisiko tinggi, yang merupakan tanggung jawab yang menimbulkan tantangan khusus dan beragam. Dimana ada kekurangan dari petugas, terutama ketika disertai dengan sejumlah besar pelaku berisiko tinggi, petugas dapat menggunakan metode represif dan ilegal untuk mengendalikan narapidana, yang dalam gilirannya cenderung menyebabkan ketegangan dan kekerasam di antara para narapidana. Dalam situasi seperti itu, petugas penjara juga mungkin lebih rentan terhadap pengkondisian dan manipulasi oleh narapidana. Lebih lanjut, tantangan serius dapat dihadapi dalam melaksanakan kegiatan rehabilitasi, yang dapat sangat bermasalah dalam kasus kelompok narapidana tertentu yang berisiko tinggi. Jelas, risiko melarikan diri jauh lebih tinggi di mana narapidana tidak dinilai dan diawasi secara khusus oleh petugas yang terlatih. Sejumlah besar narapidana berisiko tinggi dapat menghadirkan serangkaian masalah kompleks dan menantang, risiko dan kebutuhan, termasuk (keberadaan bersama) pola atau gangguan kepribadian antisocial (termasuk psikopati), masalah ketergantungan zat dan kebutuhan perawatan kesehatan mental lainnya. 
Di samping pelatihan khusus petugas penjara memiliki peran penting sebagai spesialis dibidang psikolog dan psikiater. Di sisi lain, narapidana sering berusaha untuk mengendalikan petugas dan membuat mereka melakukan hal-hal yang dilarang. Ada banyak contoh petugas internasional yang telah dikondisikan dan dimanipulasi sedemikian rupa memungkinkan narapidana untuk melarikan diri. narapidana juga dapat mencoba untuk memanipulasi atau menyuap petugas. Seperti memperoleh barang ilegal seperti ponsel atau obat-obatan dari luar penjara atau diberikan hak istimewa dan kekuasaan khusus di penjara. Pelatihan petugas untuk mengenali dan melawan manipulasi, penyediaan tingkat upah dan kondisi kerja yang sesuai, rotasi petugas secara berkala dan langkah-langkah untuk memastikan konsistensi dalam pendekatan manajemen adalah kunci untuk meminimalkan risiko korupsi dan manipulasi petugas.

\section{Kelompok Rentan dan Kesehatan Mental.}

Diskriminasi terhadap tahanan kelompok atau individu berdasarkan jenis kelamin, ras, suku, agama, kebangsaan, orientasi seksual, identitas gender atau status lainnya harus dilarang dan kebijakan dan strategi manajemen penjara harus mencakup langkah-langkah konkret untuk mengurangi dan menghilangkan semua jenis diskriminasi dalam pengelolaan tahanan berisiko tinggi.

tahanan berisiko tinggi bahkan berisiko lebih tinggi mengalami masalah kesehatan mental. Paling berisiko tinggi tahanan akan menjalani hukuman penjara yang lama, termasuk hukuman seumur hidup. Di beberapa negara, mereka mungkin menjalani hukuman seumur hidup tanpa kemungkinan pembebasan bersyarat dini (atau pembebasan bersyarat), pada orang lain mereka dapat dijatuhi hukuman mati dan menghadapi penjara karena moratoria pada hukuman mati atau proses banding yang panjang. Masa pemenjaraan yang berkepanjangan, sering ditambah dengan pengaturan kustodian terbatas, dapat memiliki dampak mendalam pada mental kesehatan tahanan berisiko tinggi tersebut. Mereka cenderung menderita dampak peningkatan isolasi sosial dan hilangnya tanggung jawab pribadi dan kontrol atas lingkungan mereka, meningkatnya ketergantungan pada lembaga pemasyarakatan, dan kemungkinan hilangnya kontak dengan keluarga dan teman. Faktor-faktor ini dapat menyebabkan perasaan kesepian yang mendalam, rasa bersalah, ketidakpastian - tentang tanggal pembebasan mereka (dan dalam kasus mereka yang di ambang hukuman mati, ketidakpastian mengenai nasib mereka) dan hilangnya keamanan karena kedekatan dengan tahanan potensial yang berpotensi kekerasan lainnya, yang membangkitkan rasa kecemasan yang konstan. Akibatnya, hukuman penjara jangka panjang bisa diperparah masalah kesehatan mental yang ada dan memunculkan masalah baru.

Kebijakan manajemen penjara perlu memperhatikan dampak jangka panjang yang berpotensi membahayakan penjara dan langkah-langkah keamanan tambahan yang diberikan kepada narapidana berisiko tinggi, dan memasukkan langkah-langkah untuk melindungi dan meningkatkan kesehatan mental dalam manajemen penjara menggunakan kebijakan dan strategi. Komponen utama dalam hal ini harus mencakup, minimal, rencana individual, yang memfasilitasi rasa tanggung jawab dan pencapaian pribadi. $\mathrm{Di}$ antara narapidana berisiko tinggi yang konstruktif; kontak dengan dunia luar; dan layanan terkait kesehatan mental, termasuk perawatan psikososial dan psikiatris perlu untuk diberikan kepada narapidana. 


\section{SIMPULAN}

Berdasarkan hasil analisis data literatur penelitian ini tentang "Manajemen Lapas Super Maximum Security dalam Perspektif Global" bahwa ada beberapa hal yang harus diperhatikan dalam membina narapidana di lapas super maximum security menurut aturan internasional diantaranya adalah perlakuan terhadap narapidana harus tetap manusiawi dan dan menjunjung tinggi martabat manusia, melakukan asesment narapidana agar dapat informasi yang tepat tentang narapidana seperti apa yang harus dihukum di lapas super maximum security, manajemen resiko yang ada di lapas super maximum security seperti resiko keamanan, pelarian, kesehatan dan kerusuhan yang mungkin terjadi, memanajemen jumlah minimal narapidana yang ditahan di lapas super maximum security, diperlukan langkah restriktif atau membatasi berdasarkan prinsip prinsip seperti berikut: legalitas, kebutuhan, proportionalitas, akuntabilitas dan nondiskriminasi, harus memanajemen kondisi lapas super maximum dengan standar yang sesuai, memperhatikan kemanan dengan memenuhi sarana fisik, sarana procedural dan keamanan yang dinamis, melakukan perekrutan yang lebih teliti dan melakukan pelatihan petugas agar mendapatkan suber daya yang ahli dibidang manajemen lapas super maximum security dan memberikan perhatian yang lebih terhadap narapidana kelompok rentan dan kesehatan mental para narapidana.

\section{DAFTAR PUSTAKA}

1. Prinsip-Prinsip Dasar tentang Penggunaan Kekuatan dan Senjata Api oleh Pejabat Penegak Hukum (Kongres Perserikatan Bangsa-Bangsa Kedelapan tentang Pencegahan Kejahatan dan Perlakuan Terhadap Pelanggar Hukum, 27 Agustus hingga 7 September 1990)

2. Prinsip-prinsip Dasar untuk Perlakuan Terhadap Narapidana (resolusi Majelis Umum 45/111 tanggal 14 Desember 1990))
3. Badan Prinsip-prinsip untuk Perlindungan Semua Orang di bawah Segala Bentuk Penahanan atau Penjara (resolusi Majelis Umum 43/173 tanggal 9 Desember 1988)

4. Kode Etik Pejabat Penegak Hukum (resolusi Majelis Umum 34/169 tanggal 17 Desember 1979)

5. Konvensi Menentang Penyiksaan dan Perlakuan atau Hukuman Lain yang Kejam, Tidak Manusiawi atau Merendahkan Martabat (resolusi Majelis Umum 39/46 tanggal 10 Desember 1984, mulai berlaku pada 26 Juni 1987)

6. Komite Eropa untuk Pencegahan Penyiksaan dan Perlakuan atau Hukuman yang Tidak Manusiawi atau Merendahkan (CPT):

Standar CPT (CPT / Inf / E (2002) 1 Rev. 2015)

Ruang hidup per narapidana di lembaga penjara: standar CPT (CPT / Inf (2015) 44)

7. Kovenan Internasional tentang Hak Sipil dan Politik (resolusi Majelis Umum 2200A (XXI) tanggal 16 Desember 1966, mulai berlaku pada tanggal 23 Maret 1976)

8. Kovenan Internasional tentang Hak Ekonomi, Sosial dan Budaya (resolusi Majelis Umum 2200A (XXI) tanggal 16 Desember 1966, mulai berlaku pada 3 Januari 1976)

9. Peraturan Minimum Standar PBB untuk Perlakuan terhadap Narapidana (Aturan Nelson Mandela)

10. Peraturan Standar Minimum PBB untuk Tindakan Non-penahanan (resolusi Majelis Umum 45/110 tanggal 14 Desember 1990)

11. Deklarasi Universal Hak Asasi Manusia (Diumumkan oleh resolusi Majelis Umum 217 A (III) 10 Desember 1948)

12. Prinsip-prinsip Yogyakarta tentang Penerapan Hukum Hak Asasi Manusia Internasional dalam kaitannya dengan Orientasi Seksual dan Identitas Gender (Panel Ahli Internasional dalam Hukum Hak Asasi Manusia Internasional dan tentang Orientasi Seksual dan Identitas Gender, Yogyakarta, Indonesia, 6 hingga 9 November 2006 ) 